\title{
Coexistence of Primary Myelodysplastic Syndrome and Multiple Myeloma
}

\section{Primer Myelodisplastik Sendrom ve Multipl Myelom Birlikteliği}

\author{
Sinem Namdaroğlu ${ }^{1}$, Emre Tekgündüz ${ }^{1}$, Sinem Bozdağ ${ }^{2}$, Ali Hakan Kaya ${ }^{1}$, Fevzi Altuntaş ${ }^{1}$ \\ ${ }^{1}$ Ankara Onkoloji Eğitim Ve Araştırma Hastanesi, Hematolji ve Kemik İliği Nakil Ünitesi, Ankara, Türkiye \\ ${ }^{2}$ Ankara Üniversitesi Tıp Fakültesi, Hematoloji Ana Bilim Dalı, Ankara, Türkiye
}

Dergiye Ulaşma Tarihi:21/06/2015 Dergiye Kabul Tarihi:06/01/2016 Doi: 10.5505/aot.2016.35220

\section{ÖZET}

Multipl miyelom (MM) ve myelodisplasik sendrom (MDS) birlikteliğine nadir rastlanmaktadır. MM tedavisinde kullanılan alkilleyici ajanların bir komplikasyonu olarak MDS gelişimi olabileceği bilinmektedir. Bu yazımızda öncesinde herhangi bir alkilleyici ajan tedavisi ve radyoterapi maruziyeti olmaksızın eşzamanlı MDS ve MM gelişen bir olgumuzu tartıştık. 63 yaşında kadın hasta, ateş ve halsizlik şikâyeti ile kliniğimize başvurdu. Laboratuvar incelemelerinde lökosit: $1.51 \mathrm{x} 109$ / L, hemoglobin: 8 g/l, MCV 85.4 fl., trombosit:

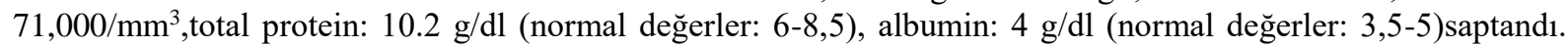
Periferik yaymada makrositer- normokrom eritrositler, anizopoikilositoz ve target hücreler izlendi. Hastanın yapılan serum immünfiksasyonunda IG G Lambda monoklonal protein saptandı. Kemik iliği aspirasyon ve biyopsisinde; $\% 70$ atipik plazma hücre infiltrasyonu ve immünhistokimyasal incelemede bu plazma hücrelerinde IG G ve lambda ile pozitif boyanma saptandı.Kemik iliği aspirasyonunda her üç seriye ait öncül hücrelerde displastik değişiklikler ve 14\% miyeloblast izlendi. Bu bulgularla hastamıza MM IG G Lambda ve MDS RAEB II tanısı koyduk. Hastaya VCD (Bortezomib, Siklofosfamid ve Deksametazon) kemoterapisi başlandı. MDS ve MM gibi farklı hücrelerden köken aldığı bilinen hastalıkların birlikteliği literatürde de görüldüğü üzere nadir değildir ve pluripotent kök hücre kökenli olduğu fikrini desteklemektedir. Bu olguyu paylaşmamızın nedeni hem literatürün bu görüşünü desteklemek hem de yeni tanı multipl myelom hastalarında görülen sitopenilerde eşlik edebilecek diğer myeloid neoplazilerinde akla getirilmesine dikkat çekmektir.

Anahtar Kelimeler: multipl miyelom, myelodisplasik sendrom, birlikteliği

\begin{abstract}
Coexistence of multiple myeloma (MM) and myelodysplastic syndrome (MDS) are rare. It has been known that coexistence of MM and MDS may occur as a complication of treatment. Due to treatment with alkylating agents myelodysplastic syndrome (MDS) may occur in multiple myeloma patients. Here we report a case of coexistent MM and MDS in a patient without history of treatment with any cytotoxic drugs or radiation therapy. A 63-years-old female was presented to our clinic with fever and weakness. Her blood counts were- WBC: $1.51 \mathrm{x}$ 109/1 - HGB: 8g/dL- MCV 85.4 fl. - PLT: 71,000/mm3. Her serum total protein elevated at $10.2 \mathrm{~g} / \mathrm{dl}$ albumin 4 $\mathrm{g} / \mathrm{dl}$. The peripheral blood smear showed macrocytic and normochromic cells, anisopoikilocytosis and target cells. Bone marrow biopsy specimen showed $70 \%$ monoclonal growth of lambda-positive plasma cells infiltration and was tri-lineage cellular dysplastic features, which included multinucleated erythroblasts and dysplastic megakaryocytes with hypolobulated nucleus. $14 \%$ myeloblasts were seen. Serum immunofixation studies showed a monoclonal IgG lambda. These findings were characteristic for Primary MDS RAEB II and MM. We started treatment for her multiple myeloma with VCD (bortezomib, cyclophosphamide and dexamethasone). Presence the coexistence of both diseases originating from different cell lines may not be rare as they known. There have been some reports of coexistence of MDS and myeloma; supporting the idea of pluripotent stem cell origin of the disease. We suggest that MM patients administrating with cytopenie should be evaluated for coexistent myeloid neoplasms.
\end{abstract}

Keywords: multiple myeloma, myelodysplastic syndrome, coexistence 


\section{Introduction:}

Myelodysplastic syndrome (MDS) is a colonal disorder of the hematopoietic system characterized by dysplasia, presence of ineffective hematopoiesis, peripheral cytopenias and an increased risk of transformation to acute myeloid leukemia (AML) (1). Multiple myeloma $(\mathrm{MM})$ is a plasma cell malignancy that affect Bcells maturations, producer of immunoglobulines and bone marrow (BM) infiltration (2). The coexistence of both diseases are rare. It has been known that coexistence of multiple myeloma (MM) and myelodysplastic syndrome (MDS) may occur as a complication of treatment. Due to treatment with alkylating agents in multiple myeloma patients, myelodysplastic syndrome (MDS) can be occur.

Chemotherapy induced MDS (secondary MDS) is more resistant to therapy and have a poor prognosis (3).

Here we report a case of coexistent MM and MDS in a patient without history of treatment with any cytotoxic drugs or radiation therapy.

\section{Case Report:}

A 63-years-old female was presented to our clinic with fever and weakness. Her blood counts were- WBC: $1.51 \times 109 / 1-\mathrm{HGB}: 8 \mathrm{~g} / \mathrm{dL}-$ MCV 85.4 fl.- PLT: 71,000/mm3. Her serum total protein elevated at $10.2 \mathrm{~g} / \mathrm{dl}$, albumin 4 $\mathrm{g} / \mathrm{dl}$. Serum iron levels were normal and serum ferritin was elevated at $539 \mathrm{ng} / \mathrm{ml}$. The peripheral blood smear showed normochromic erythrocytes, anisopoikilocytosis and target cells. Bone marrow biopsy specimen showed $70 \%$ monoclonal growth of lambda-positive plasma cells infiltration and were tri-lineage cellular dysplastic features, which included multinucleated erythroblasts, dysplastic megakaryocytes with hypolobulated nucleus and $14 \%$ myeloblasts were seen. Serum immunoglobulins showed an elevated IgG (37.6 $\mathrm{g} / \mathrm{l})$ with increase in lambda free light chains $(4.68 \mathrm{~g} / \mathrm{l})$, serum protein electrophoresis and serum immunofixation studies showed a monoclonal IgG lambda. Urine protein electrophoresis and immunofixation studies showed a monoclonal lambda light chain.

Her radiologic full body-bone survey showed no lytic lesions. These findings were charasteristic for MDS RAEB II and MM. Karyotype was normal: 46, XX. FISH analysis did not find any chromosomal abnormality.

Our patient was diagnosed with coexistence MM IgG Lambda and Primary MDS-RAEB II. We started treatment for her multiple myeloma with VCD (bortezomib, cyclophosphamide and dexamethasone). After receive 4 cycles of with $\mathrm{VCD}$ regimen then patient achieve Complete response (CR).

\section{Discussion:}

Our patient was diagnosed with coexistence MM and MDS. Multiple myeloma $(\mathrm{MM})$ is a plasma cell malignancy, representing $1 \%$ of all cancers and $10 \%$ of hematologic neoplasms. Incidence increases with age, the median age at diagnosis is 70 years. (4)

The myelodysplastic syndrom (MDS) is a clonal disorder of the hematopoietic system and occur in older adults with a median age of 70 years. The overall annual incidence of MDS is 320 per $100,000(5)$.

Myelodysplastic syndrome (MDS) is a hematological malignancy characterized by dysplasia and ineffective hematopoiesis. The lineage affected in this pathology is the myeloid one. Plasma cells disorders (PCD) affect B-cells, producer of immunoglobulines. Despite the different pathogenesis of these hematologic diseases, but there have been some reports of coexistenceof MDS and myeloma supporting the idea of pluripotent stem cell origin of the disease. Therapy-related MDS following chemotherapy for MM is well recognized but the coexistence of both diseases are rare.

Coppelstone et al. proposed that both multiple myeloma and MDS can produce growth factors which affect the other cell line (6). This hypothes was sustained by Sefer at al. who established elevated IL-6 levels in both disorders (7). 
Mufti et. al. showed in MM patients some unstable haematopoietic clones, they can transformed into myeloid neoplasms so that simultaneous de novo diseases both myeloid and lymphoid lineages can occur (8).

Nilsson et al have demonstrated that a $5 \mathrm{q}$ deletion-which is well known specific clonal alteration of MDS - may occur in hematopoietic stem cells (HSCs) with a combined lymphomyeloid potential (9). The coexistence of MM and MDS arising from different cell lines can be explained by this data.

In addition; contrary to Mufti, Tsiara et. al. suggested that malignant transformation of a single precursor cell has ability to transformate either lymphoid and myeloid neoplasms as possible etiology of coexistence of both diseases orginating from different cell lines (10). Both in MM and MDS, some cytogenetic abnormalities are common as deletion of chromosome 13, this data is compatible with their theory.

Dewald et al. have shown some specific chromosome alterations for MDS which present in MM patients, who had leucopenia and had the poor prognosis. (11).

Várkonyi et al showed that the hemochromatosis gene mutations (C282Y and H63D) found with higher rate in MM patients who have low WBC at presentation. They also showed that $49 \%$ of MDS patients positive for either HFE variant which could be tested for another indirect approach to make MDS diagnosis more probable $(12,13)$.

\section{Conclusion:}

In this case we reported a patient diagnosed with coexistence both $\mathrm{MM}$ and Primary MDS. Presence the coexistence of both diseases originating from different cell lines may not be rare as they known. Despite the different cell origin of these hematologic diseases, published reports of coexistence of MDS and myeloma supporting the idea of pluripotent stem cell origin of the disease. We suggest that MM patients administrating with cytopenie should be evaluated for coexistent myeloid neoplasm. In literature there are some similar reports, support this.

\section{Conflict of interest: None}

\section{References:}

1. Abdel-Wahab O, and Figueroa ME. Interpreting new molecular genetics in myelodysplastic syndromes. ASH Education Program Book2012.1 (2012): 56-64.

2. Palumbo A, Cavallo F. Have drug combinations supplanted stem cell transplantation in myeloma? Blood: the journal of hematology (Washington, DC: American Society of Hematology), Vol. 120, No. 24 (2012), p. 46924698

3. Mehendale S, Patel P, Lindgren V, Rondelli D, Gaitonde S. Coexistent systemic amyloidosis, multiple myeloma, and refractory anemia with ringed sideroblasts in a previously untreated patient. International Journal of Case Reports and Images 2011; 2:1-4.

4. Altekruse SF, Kosary C, Krapcho M, Neyman N, Aminou R, Waldron W. SEER Cancer Statistics Review, 1975-2007. Bethesda, MD: National Cancer Institute; 2010. [7 September 2010].

5. Aul C, Gattermann N, Schneider W. Age related incidence and other epidemiologic aspects of myelodysplastic syndromes. Br J Haematol 1992; 82:358367.

6. Coppelstone JA, Manoharan A, Catovsky D, et al: Simultaneous or spontaneous occurrence of lympho- and myeloproliferative disorders: A report of four cases. Br J Haematol. 1981;48:111-116.

7. Sefer D, Marisavljevic D, Bogdanovic A, at al: Circulating Interleukin-6 (IL-6) in patients with myelodysplastic syndromes. Leukemia Res; 1999, 23, 78

8. Mufti GJ, Hamblin TJ, Clein GP, Race C.Coexistent myelodysplasia and plasma cell neoplasia. Br J Haematol 1983; 54:91-96

9. Nilsson L, Astrand-Grundstörm I, Arvidsson I, et al. Isolation and characterization of hematopoietic progenitor stem cells in $5 \mathrm{q}$ deleted myelodysplastic syndromes: evidence for involvement at the hematopoietic stem cell level. Blood, 2000; 96:2012-2021.

10.Tsiara S, Economou G, Panteli A, Isaakidis P, Kapsali E and Bourantas KL. Coexistence of myelodysplastic syndrome and multiple myeloma. J Exp Clin Cancer Res 1999; 18:565-566.

11.Dewald GW, Kyle RA, Hicks GA, Greipp PR.The clinical significance of cytogenetic studies in 100 patients with multiple myeloma, plasma cell leukemia, or amyloidosis. Blood, 1985; 66:380-390.

12.Várkonyi J, Demeter J, Tordai A, Andrikovics H. The significance of the Hemochromatosis genetic variants in multiple myeloma in comparison to that of myelodysplastic syndrome. Ann.Hematol. 2006; 85: 869-871 
13. Várkonyi J, Tarkovács G, Karádi I, at al. High incidence of hemochromatosis gene mutations in the myelodysplastic syndrome: The Budapest study on 50 patients. Acta Haematol. 2003; 109: 64-67. 